\title{
THE METABOLISM OF ORALLY ADMINISTERED 4-METHYL-2-THIOURACIL IN COCKERELS
}

\author{
by \\ K. VAN ASPEREN \\ Laboratory of Veterinary Physiology, University \\ Utrecht (Netherlands)
}

\section{INTRODUCTION}

The metabolism of thiouracil was extensively investigated by WiLliams $c . s^{13}$ in rats and man. According to the results of these investigations orally administered thiouracil is rapidly absorbed from the digestive tract, especially from stomach and small intestine; faeces contain no thiouracil. About $15 \%$ of the administered dose (I00-200 mg for man) is destroyed in the digestive tract, the remainder is distributed among all tissues and body fluids. Relatively high concentrations may be found in the pituitary, thyroid, adrenals and bone marrow, lower concentrations in skin and muscles. Tissue concentrations are much higher than those in blood, blood cells contain several times more thiouracil than plasma. About $1 / 3$ of the quantity administered is excreted with urine, about $50 \%$ is destroyed in the body. Blood concentrations are maximal about I-2 hours after administration.

In I949 a number of papers was issued by the National Council for agricultural research T.N.O. in the Netherlands, published by several authors and all dealing with the use of anti-thyroids for fattening purposes. Two of them may be especially mentioned here. BEZEM, LEVER AND BRUNNEKREEFT ${ }^{5}$ studied the absorption, distribution and excretion of methyl-thiouracil (henceforth to be indicated by the letters MTU) in cocks by making use of a preparation containing radio-active sulphur. They found a rather rapid elimination of MTU by the organism, after 24 hours $60-70 \%$ of the active substance is excreted, after at least 96 hours it has disappeared almost completely from the body. After 24 hours only very small amounts could be detected in most organs, concentrations in thyroid tissue, however, were relatively high. After repeated dosage there proved to be a tendency to cumulation; some facts point to a greater retention of MTU from the later doses. VAN GENDEREN, VAN LIER AND BEZEM ${ }^{10}$ investigated the MTU content of the flesh and some organs of cows, fattened by a daily addition of $5 \mathrm{mg}$ MTU to the food during 6 weeks. For muscle tissue the results of their determinations varied between 0 and $4 \mathrm{mg} / \mathrm{kg}$, for liver between $o$ and $8 \mathrm{mg} / \mathrm{kg}$, in thyroid tissue, however, an average content of $65 \mathrm{mg} / \mathrm{kg}$ was found. The authors conclude that no toxic effects from the consumption of MTU-fattened cows need to be expected.

These last two papers only came to my notice after the termination of my own experiments.

References p. r6T. 
THE PROBLEM

Our problem was the following: If a definite quantity of MTU daily is given per os, a. how much may then be excreted daily

b. what rate of excretion may be found at various times in the 24 -hours period after the administration of the MTU

c. what are the MTU-concentrations in tissues and body fluids at various times after the administration

I. in blood plasma (blood);

2. in muscle tissue;

3. in thyroid tissue.

\section{DETERMINATION METHODS}

A detailed description of the methods used for examination of blood plasma and excrements is to be found in a former paper (VAN ASPEREN ${ }^{3}$ ), for muscle tissue the method, described by VAN Genderen, VAN LIER AND DE Beus ${ }^{2}$ was used. For the determination in thyroid tissue we used this same method, slightly modified by us to make it suitable to the small amounts of material that were at our disposal. As no recovery values for the thyroid determinations could be obtained, the results of the latter tend to be rather uncertain, which we should take into account in interpreting the results of our experiments.

\section{EXPERIMENTAL}

\section{Arrangement of the experiments}

Two series of experiments and a rather large number of more incidental experiments were performed. In the first series 6 cockerels, aged 2 to $3 \frac{1}{2}$ months, received daily doses of 40 or $80 \mathrm{mg}$ MTU during 2 to 5 weeks, in the second series only a small number of MTU doses was given to each animal. In this series, as in the first, ten cockerels were used, all 3 to 4 months of age. Age, however, proved to be of no importance; the results obtained with adult cocks did not differ from those in the series. The cockerels were kept in battery cages and were fed a fattening diet containing grains and buttermilk. MTU was administered in gelatine capsules, so the amount taken by the animals could be exactly determined. All cockerels in the series were regularly weighed. In the first series administration of MTU was continued for several weeks. As the state of health of several experimental animals proved to be rather poor, probably in consequence of the prolonged administration of MTU, the animals in the second series received MTU for a short time only (I, 4,7 or 8 daily doses of $80 \mathrm{mg}$ MTU).

\section{Growth rate of the animals}

In accordance with VAN Albada AND UBbels ${ }^{1}$, ANDREws aND SCHNETZLER ${ }^{2}$, Blakely and ANderson ${ }^{6}$ (with Turkey broilers), Kempster and Turner ${ }^{11}$, and Domm AND BLIVAISs ${ }^{7}$, we found a growth retarding effect of MTU if $40 \mathrm{mg}$ doses were used after about 20 days ( 4 animals), and if $80 \mathrm{mg}$ doses were used after about 5 days ( 2 animals). Whereas the controls ( 4 animals) showed a steady increase in weight, the experimental animals finally lost weight. This growth retardment may perhaps be due to a decrease of motility of the digestive tract under the influence of MTU, this slowing of intestinal movements causing loss of appetite, as was suggested by FRENS ${ }^{8}$ for cows fattened with MTU.

References $p . I 6 r$. 


\section{Excretion of $M T U$ during the experimental period}

This was studied by the first series of experiments, performed with ro animals. Of these 4 received $40 \mathrm{mg}$ MTU daily, 2 received $80 \mathrm{mg}$ daily and 4 served as controls. MTU was always given at 9,30 a.m., consequently with intervals of exactly 24 hours. Table I shows the total amount of MTU excreted in 24 hours, following the administration of the drug, on successive days after the beginning of the experiment.

TABLE I

EXCRETION OF METHYLTHIOURACIL

All data indicate the excreted amounts of MTU expressed in milligrammes

\begin{tabular}{|c|c|c|c|c|c|c|}
\hline & \multicolumn{4}{|c|}{ Dosis $40 \mathrm{mg} \mathrm{MTU} / \mathrm{day}$} & \multirow{2}{*}{\multicolumn{2}{|c|}{$\frac{80 \mathrm{mg} \mathrm{MTU} / \mathrm{day}}{\text { Animal }}$}} \\
\hline & \multicolumn{4}{|c|}{ Animal } & & \\
\hline & $\mathrm{I}$ & 2 & 3 & 4 & 5 & 6 \\
\hline $\begin{array}{l}\text { Ist day } \\
\text { 2nd day } \\
3^{\text {rd day }} \\
4^{\text {th day }} \\
6 \text { th day } \\
7^{\text {th day }} \\
\text { 8th day } \\
\text { 9th day } \\
\text { Ioth day } \\
\text { I Ith day } \\
\text { I } 3^{\text {th day }} \\
\text { I } 4^{\text {th day }} \\
\text { I6th day } \\
\text { I } 8 \text { th day } \\
\text { 2 Ist day } \\
\text { 25th day } \\
\text { 28th day }\end{array}$ & $\begin{array}{l}15.2 \\
19.9 \\
19.2 \\
24.2 \\
19.4 \\
19.1 \\
- \\
19.0 \\
- \\
24.4 \\
24.5 \\
25.6 \\
25.5 \\
- \\
-\end{array}$ & $\begin{array}{l}21.2 \\
21.7 \\
20.6 \\
19.2 \\
22.1 \\
24.6 \\
17.4 \\
21.9 \\
17.6 \\
23.3 \\
22.9 \\
27.2 \\
19.4\end{array}$ & $\begin{array}{l}20.9 \\
- \\
23.7 \\
21.4 \\
18.5 \\
- \\
23.7 \\
- \\
23.1 \\
19.5 \\
23.2 \\
- \\
26.0 \\
25.1 \\
-\end{array}$ & $\begin{array}{l}20.2 \\
- \\
20.7 \\
27.7 \\
18.3 \\
- \\
22.4 \\
- \\
21.7 \\
26.0 \\
24.0 \\
- \\
29.6 \\
- \\
29.8\end{array}$ & $\begin{array}{l}3^{8.7} \\
- \\
36.4 \\
38.9 \\
- \\
51.6 \\
- \\
- \\
51.9 \\
- \\
- \\
- \\
-\end{array}$ & $\begin{array}{l}39.2 \\
38.3 \\
\overline{38.3} \\
- \\
- \\
- \\
- \\
- \\
- \\
- \\
-\end{array}$ \\
\hline
\end{tabular}

From these data the following conclusions may be drawn:

a. Of a daily dose of $40 \mathrm{mg}$ MTU on the average about $22 \mathrm{mg}$ or $55 \%$ is excreted within 24 hours. The variation of the values obtained is rather small.

b. The excreted percentage is nearly constant over the experimental period, notwithstanding the very important gain in weight of the experimental animals.

c. From the fact that the amounts excreted on the first day and on the following days are nearly equal, the conclusion may be drawn that excretion is almost complete within 24 hours after administration. This conclusion will be confirmed by a number of experiments which will be described below.

d. From a daily dose of $80 \mathrm{mg}$ MTU, an average of about $40 \mathrm{mg}$ or $50 \%$ is excreted within 24 hours. Data on the 9 th and $13^{\text {th }}$ day are very high for animal No. $5(65 \%)$, very low for animal No. $6(42 \%)$. The reason is unknown.

We shall prove below that excretion of MTU takes place entirely by way of the kidneys, and that passage of MTU through the digestive tract does not occur.

4. The rate of excretion as determined at different times after the administration of $M T U$

This was studied by sampling the excrements at relatively small intervals. Weight and MTU content of each sample were determined, so that the total quantity of MTU References p. $16 \mathrm{I}$. 
and the excretion rate could be calculated. Table II shows the results obtained with 3 cockerels of the first series in the 24 hours period, following the first administration of MTU. Experiments which will not be described here showed the course of excretion, following the administration of a later dose, after some weeks of daily administration of MTU, to be nearly the same. This again proves that excretion is practically terminated within 24 hours after administration. Direct evidence is produced by the data in Table III, concerning 4 experiments with full-grown cocks.

TABLE II

DAILY COURSE OF EXCRETION (cockerels)

$\mathrm{a}=$ quantity of excrements, in grammes.

$\mathrm{b}=$ total amount of MTU excreted, in milligrammes.

$\mathrm{c}=$ excretion rate, in milligrammes MTU/hour.

\begin{tabular}{|c|c|c|c|c|c|c|c|c|c|}
\hline \multirow{2}{*}{$\begin{array}{l}\text { Period } \\
\text { (hours) }\end{array}$} & \multicolumn{3}{|c|}{$\begin{array}{c}\text { Animal i (40 mg MTU) } \\
965 \text { gram }\end{array}$} & \multicolumn{3}{|c|}{$\begin{array}{c}\text { Animal } 3 \text { (40 mg MTU) } \\
\text { I } 160 \text { gram }\end{array}$} & \multicolumn{3}{|c|}{$\begin{array}{c}\text { Animal } 6 \text { ( } 80 \mathrm{mg} \text { MTU) } \\
\text { I } 7 \text { I } 0 \text { gram }\end{array}$} \\
\hline & $\mathrm{a}$ & $b$ & C & a & $\mathbf{b}$ & $\mathrm{C}$ & a & b & $c$ \\
\hline $0-2.5$ & I6 & 0.37 & 0.15 & $\mathbf{I} 7$ & 0.65 & 0.26 & I I & $7 \cdot 52$ & 3.01 \\
\hline $2 \cdot 5-6$ & $2 I$ & 4.73 & 1. 35 & 32 & 9.12 & $2.6 \mathrm{I}$ & 28 & 14.65 & 4.19 \\
\hline 6-II & 26 & 5.24 & 1.05 & 36 & 7.44 & I. 49 & $3 I$ & I0.89 & 2.18 \\
\hline I I -24 & 69 & 4.89 & 0.38 & 55 & $3.7^{\circ}$ & 0.28 & 73 & 6.12 & 0.47 \\
\hline $0-24$ & I 32 & I 5.23 & 0.63 & I 40 & 20.91 & 0.87 & 143 & 39.18 & I. 63 \\
\hline
\end{tabular}

The data of Tables II and III inform us that no or only little MTU is excreted after more than 24 hours. Most of the excretion takes place in the first 12 hours and the excretion rate in the second I2 hours has fallen to a fairly low value. Very shortly after the administration MTU may be detected in the excrements; the excretion rate is maximal 2 to 6 hours after the administration and then a rather rapid decline takes place. A full-grown cock (No. D, not to be found in Table III), receiving $5^{\circ} \mathrm{mg}$ MTU, excreted $2.77 \mathrm{mg}$ in the first hour, not less than $19.07 \mathrm{mg}$ was excreted within 8 hours, the total quantity excreted in 23.5 hours amounting to $25.93 \mathrm{mg}$.

\section{Concentrations of MTU in blood plasma, muscle tissue and thyroid}

Table IV shows the data obtained with 6 cockerels of the first series and 2 fullgrown cocks. These animals were killed at various times during the day. So we were able to study the influence of two factors:

a. the number of MTU doses which had been administered previously (each animal received only one dose of MTU daily; all doses were always given on successive days);

b. the time interval between the last dose of MTU and slaughter.

It may be noted here that all material (plasma, muscle tissue, thyroid) which could not be treated immediately was kept in a refrigerator.

Refarences $p . I \sigma_{I}$. 
TABLE III

THE COURSE OF EXCRETION (full-grown cocks)

For the meaning of $a, b$ and $c$ : see above (Table II)

\begin{tabular}{|c|c|c|c|c|c|c|c|}
\hline $\begin{array}{c}\text { Dose } \\
\text { 8o } \mathrm{mg} \text { MTU }\end{array}$ & \multicolumn{3}{|c|}{$\begin{array}{c}\text { Animal A } \\
3000 \mathrm{~g}\end{array}$} & $\begin{array}{c}\text { Dose } \\
\text { 80 } \mathrm{mg} \mathrm{MTU}\end{array}$ & \multicolumn{3}{|c|}{$\begin{array}{c}\text { Animal B } \\
3800 \mathrm{~g}\end{array}$} \\
\hline $\begin{array}{l}\text { Period } \\
\text { (hours) }\end{array}$ & $\mathrm{a}$ & $b$ & $\mathrm{C}$ & $\begin{array}{l}\text { Period } \\
\text { (hours) }\end{array}$ & 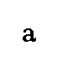 & $\mathrm{b}$ & c \\
\hline $0-2.7$ & $3^{\circ}$ & $5 \cdot 45$ & 2.04 & $0-2.0$ & $5 I$ & 3.62 & I. $8 \mathrm{I}$ \\
\hline $2.7-5.0$ & I9 & 5.62 & 2.41 & $2.0-4.5$ & $3^{2}$ & 6.53 & 2.61 \\
\hline $5.0-7 \cdot 3$ & 22 & 6.27 & 2.69 & $4.5-7.0$ & 37 & 9.14 & 3.66 \\
\hline $7 \cdot 3-13.0$ & 25 & $8.5^{6}$ & I.5I & $7.0-x 2.0$ & 35 & I I.I 3 & 2.23 \\
\hline I $3.0-24.0$ & 57 & I 3.47 & 1.22 & I $2.0-24.5$ & $9^{8}$ & 13.03 & 1.04 \\
\hline $24.0-29 \cdot 3$ & 34 & $2.4^{\mathrm{I}}$ & 0.45 & $24 \cdot 5-29 \cdot 5$ & $5^{8}$ & 3.02 & 0.60 \\
\hline $29.3-48.0$ & $14^{8}$ & - & - & $29.5-48.5$ & I 44 & 一 & - \\
\hline $0-24.0$ & I 53 & $39 \cdot 37$ & I. 64 & $0-24.5$ & 253 & 43.45 & 1.77 \\
\hline $\begin{array}{c}\text { Dose } \\
80 \mathrm{mg} \mathrm{MTU}\end{array}$ & & $\begin{array}{l}\text { nimal } \\
49008\end{array}$ & & $\begin{array}{c}\text { Dose } \\
\text { I00 mg MTU }\end{array}$ & & $\begin{array}{l}\text { nimal } \\
4900 g\end{array}$ & \\
\hline $\begin{array}{l}\text { Period } \\
\text { (hours) }\end{array}$ & a & $\mathrm{b}$ & $\mathrm{c}$ & $\begin{array}{l}\text { Period } \\
\text { (hours) }\end{array}$ & $\mathrm{a}$ & $\mathrm{b}$ & $\mathrm{c}$ \\
\hline$O-I . I$ & 19 & 0.21 & 0.20 & $0-2.0$ & 42 & I. 47 & 0.74 \\
\hline I. I -2.6 & 32 & 7.21 & $4.8 \mathrm{I}$ & $2.0-4.5$ & 75 & $9 \cdot 3^{8}$ & 3.75 \\
\hline $2.6-7.8$ & 85 & I 2.45 & $2.4 \mathrm{I}$ & $4 \cdot 5-7 \cdot 5$ & 49 & II. .03 & 3.68 \\
\hline $7.8-13.4$ & 54 & $9 \cdot 34$ & I. 65 & $7 \cdot 5-11.5$ & 35 & $10.5^{\circ}$ & 2.63 \\
\hline $13.4-23.7$ & I I 2 & 6.07 & 0.59 & I I. $5-24.0$ & 100 & I 5.00 & I. 20 \\
\hline $23.7-31.8$ & 140 & 0.0 & 0 & $24.0-32.0$ & 206 & 0.0 & 0 \\
\hline $31.8-48.0$ & 147 & 0.0 & 0 & $32.0-48.5$ & I 53 & 0.0 & 0 \\
\hline $0-23.7$ & 302 & 35.28 & 1.49 & $0-24.0$ & $30 \mathrm{I}$ & $47 \cdot 3^{8}$ & 1.97 \\
\hline
\end{tabular}


TABLE IV

CONCENTRATIONS OF MTU IN BLOOD PLASMA, MUSCLE TISSUE AND THYROID

$a=$ weight on the day of slaughter, in grammes.

$\mathrm{b}=$ total number of daily doses of MTU, administered during the exper. period (see text).

$\mathrm{c}=$ the amount of a single dose, in milligrammes.

$\mathrm{d}=$ time interval between the last dose and slaughter, in hours.

w.t. $=$ total weight of both thyroids, in milligrammes.

"plasma", "muscle" and "thyroids" indicate the concentrations of MTU in milligrammes percent

\begin{tabular}{c||c|c|c|c|c|c|c|c}
\hline No. & $\mathrm{a}$ & $\mathrm{b}$ & $\mathrm{c}$ & $\mathrm{d}$ & plasma & muscle & w.t. & thyroids \\
\hline $\mathrm{I}$ & $\mathrm{I} 4 \mathrm{IO}$ & $\mathrm{I} 9$ & 40 & 23.5 & 0.4 & $0 . \mathrm{I}$ & 207 & - \\
\hline 2 & $\mathrm{I} 650$ & 35 & 40 & 6.5 & 0.2 & 0.6 & 553 & \} \\
\hline 4 & $\mathrm{I} 670$ & 32 & 40 & 22.5 & 0.4 & 0.9 & 239 & \} \\
\hline 3 & $\mathrm{I} 570$ & 30 & 40 & 2 & 3.6 & 2.4 & 583 & \} \\
\hline 6 & $\mathrm{I} 525$ & $\mathrm{I} 7$ & 80 & 24.5 & - & 4.7 & $15 \mathrm{I}$ & \} \\
\hline 5 & $\mathrm{I} 680$ & $\mathrm{I} 7$ & 80 & $4 \mathrm{days}$ & 0.0 & 0.0 & $5 \mathrm{I} 8$ & 0.0 \\
\hline $\mathrm{R}$ & 3820 & $\mathrm{I}$ & $\mathrm{I} 20$ & 4.5 & 3.0 & 2.5 & - & - \\
\hline $\mathrm{S}$ & 3810 & $\mathrm{I}$ & $\mathrm{I} 20$ & $2 \mathrm{I}$ & $2.8 ?$ & 0.9 & $3 \mathrm{I} 7$ & - \\
\hline
\end{tabular}

The thyroids of No. 2 and No. 4 and those of No. 3 and No. 6 were pooled and the MTU content determined in the obtained mixtures of thyroid tissue. Animal No. 6 was killed while already dying; crop and gizzard still contained considerable amounts of food and $37 \mathrm{mg}$ and $35 \mathrm{mg}$ MTU respectively, more than 24 hours after the latest dose of MTU of $80 \mathrm{mg}$. This demonstrates clearly the slackening of vital processes in this animal. Only one thyroid, weighing I5I $\mathrm{mg}$, was found in this animal.

Four animals of the first series served as controls and received no MTU at all. They were killed to obtain blank values in addition to those already formerly acquired. The increase of thyroid weight by administration of MTU is clearly indicated by the fact that all thyroids of the control animals together weighed only $593 \mathrm{mg}$ (the separate weights of thyroids of 4 control animals were: 50 and $60 ; 76$ and $53 ; 64$ and $107 ; 183 \mathrm{mg}$, the last one being single).

When studying the data of Table IV one observes a strong tendency for concentrations to be highest during the first few hours after the administration and to be low at the end of the 24 hours period following administration of MTU. There are some deviations however, the most striking being the very high concentration of MTU in the flesh of No. 6. However, this may be explained by the very bad health of this animal, already discussed above. A distinct relation exists between the concentrations in plasma, muscle tissue and thyroid, the latter being somewhat higher. 
The duration of administration of MTU (number of doses) proves to be a factor of no importance. Confirmation of this fact will be given by the second series of experiments, to be discussed below.

In order to acquire knowledge about the concentrations of MTU in the blood plasma at different hours of the day, blood was taken from a number of animals at different times after the administration. The results are to be found in Table $\mathrm{V}$.

Data of Table $\mathrm{V}$ are in rather good agreement with the following conception:

a. the maximal concentrations of MTU in plasma are reached in 3-5 hours.

b. after this a rather rapid decline of the concentrations takes place, and mostly 20-24 hours after the administration the concentrations are very low.

TABLE $\mathrm{V}$

CONCENTRATIONS OF MTU IN BLOOD PLASMA

$\mathrm{a}=$ The total number of MTU-doses, administered in the previous period (one dose daily at $9 \mathrm{~h} 30$ ).

$\mathrm{b}=$ The amount of MTU administered daily.

Times at the heads of the columns indicate times passed after the last administration of MTU; immediately underneath the concentrations of MTU in the blood plasma in milligrammes per cent.

\begin{tabular}{|c|c|c|c|c|c|c|}
\hline \multirow{2}{*}{$\begin{array}{r}\text { Animal } 2 \\
1650 \mathrm{~g}\end{array}$} & $\mathrm{a}$ & b & $o \mathrm{~min}$ & $150 \mathrm{~min}$ & $390 \mathrm{~min}$ & \\
\hline & 35 & $40 \mathrm{mg}$ & 0.4 & I. 4 & 0.2 & \\
\hline \multirow{2}{*}{$\begin{array}{r}\text { Animal } 4 \\
1670 \mathrm{~g}\end{array}$} & $\mathrm{a}$ & $\mathrm{b}$ & $o$ min & I $50 \mathrm{~min}$ & I $350 \mathrm{~min}$ & \\
\hline & 32 & $40 \mathrm{mg}$ & 0.8 & 3.2 & 0.4 & \\
\hline \multirow{2}{*}{$\begin{array}{c}\text { Animal R } \\
3820 \mathrm{~g}\end{array}$} & a & $b$ & $\circ \mathrm{min}$ & $90 \mathrm{~min}$ & $27^{\circ} \mathrm{min}$ & \\
\hline & I & $120 \mathrm{mg}$ & 0 & 1.0 & 3.0 & \\
\hline \multirow{2}{*}{$\begin{array}{l}\text { Animal S } \\
\pm 3^{800 \mathrm{~g}}\end{array}$} & $a$ & b & $\circ \min$ & $225 \mathrm{~min}$ & $3^{60} \mathrm{~min}$ & $\mathrm{I} 380 \mathrm{~min}$ \\
\hline & I & $120 \mathrm{mg}$ & 0 & 2.6 & I. 4 & 0 \\
\hline \multirow{2}{*}{$\begin{array}{c}\text { Animal S } \\
3810 \mathrm{~g}\end{array}$} & $a$ & b & $o$ min & $240 \mathrm{~min}$ & $390 \mathrm{~min}$ & $1260 \mathrm{~min}$ \\
\hline & $1^{*}$ & $120 \mathrm{mg}$ & $o$ & 3.8 & 2.6 & $2.8 ?$ \\
\hline \multirow{2}{*}{$\begin{array}{l}\text { Animal } T \\
\text { full-grown }\end{array}$} & $a$ & $b$ & $0 \min$ & $35 \mathrm{~min}$ & $65 \mathrm{~min}$ & $2 \mathrm{I} 5 \mathrm{~min}$ \\
\hline & 1 & $50 \mathrm{mg}$ & 0 & 0.5 & 0.7 & I.9 \\
\hline
\end{tabular}

* Animal $S$ was used twice with an interval of ro days. 
Two more determinations show that the concentrations of MTU in thyroid are higher than those in muscle tissue. The thyroids (together weighing $930 \mathrm{mg}$ ) of a fullgrown cock which had been receiving $60 \mathrm{mg}$ MTU daily for about 2 months contained $2.4 \mathrm{mg} \% \mathrm{MTU}$, the flesh only $0.4 \mathrm{mg} \%$. The concentration of MTU in 3 thyroids (obtained from two cocks, total weight $644 \mathrm{mg}$ ) proved to be $3.9 \mathrm{mg} \%$, muscle tissue (of both animals) only contained $0.8 \mathrm{mg} \%$.

As to the influence of the two factors mentioned above (a. number of doses; $b$. time interval after the last dose) the results of the second series of experiments yield very valuable evidence in favour of the conclusions based on the data of Table IV. Table VI shows the data obtained with Io animals, one of these serving as a control, the other 9 receiving $\mathrm{I}, 4,7$ or 8 doses of $80 \mathrm{mg}$ MTU on successive days.

TABLE VI

CONCENTRATIONS OF MTU IN BLOOD PLASMA AND MUSCLE TISSUE

Weight $=$ weight of the animal on the day of slaughter, in grammes.

Doses = number of doses (one dose daily, amounting to $80 \mathrm{mg}$ MTU).

Interval = time interval between the last dose and slaughter, in hours.

"Plasma" and "Muscle" $=$ concentrations of MTU in blood plasma and muscle tissue at the time of slaughter, in milligrammes per cent.

\begin{tabular}{|c|c|c|c|c|c|}
\hline No. & Weight & Doses & Interval & Plasma & Muscle \\
\hline I I & I 700 & $I X$ & 5 & 3.9 & 2.3 \\
\hline 12 & 1780 & $\mathbf{I} \times$ & 5 & $3 \cdot 4$ & 2.3 \\
\hline I 3 & 2100 & $\mathbf{I} \times$ & 2 & 2.7 & I. 8 \\
\hline$I_{4}$ & 2110 & $1 \times$ & 12 & I. 7 & 0.7 \\
\hline I 5 & I 4 IO & $4 \times$ & 22.5 & 0,7 & 0.3 \\
\hline 16 & 1920 & $4 \times$ & 5 & 2,0 & 1.2 \\
\hline 17 & 2480 & $7 \times$ & 21.5 & 0.6 & 0.0 \\
\hline 18 & $235^{\circ}$ & $8 \times$ & 5 & 3.5 & 2.0 \\
\hline 19 & $177^{\circ}$ & I $x$ & 22.5 & 0.0 & 0.2 \\
\hline 20 & 2670 & $0 x$ & - & 0.0 & 0.0 \\
\hline
\end{tabular}

Shortly (2-5 hours) after the administration of MTU in both blood plasma (2.0$3.9 \mathrm{mg} \%$ ) and muscle tissue (I.2-2.3 $\mathrm{mg} \%$ ) high concentrations of MTU are found. After about 22 hours (2I.5-22.5 hours) however the MTU values for plasma (0.0-0.7 
$\mathrm{mg} \%$ ) and for muscles (0.0-0.3 $\mathrm{mg} \%$ ) are low. The concentration values found for Animal I4 twelve hours after the administration lie just between the values mentioned above. There proves to be no relation between the concentrations of MTU found in plasma and muscle tissue and the duration of administration of MTU (number of doses). Cumulation of MTU after repeated administration does not occur.

As was shown by a number of experimental data not mentioned here, MTU is equally distributed among the muscle tissues of the body. Very probably there also exists an equal distribution of MTU over blood cells and plasma, this, however, was not exhaustively studied. With WRIGHT ${ }^{\mathbf{1 4}}$ we believe that the opinion of WrLLIAMs ${ }^{13}$ that blood cells contain several times more MTU than plasma is not correct.

6. Estimation of the total amount of $M T U$ in the body (with exception of the digestive tract)

Our starting point was that contents of MTU in all parts of the body are nearly the same as those in muscle tissue. This may be wrong, but our own experience and data in literature teach us that MTU concentrations in most organs and body fluids are at least as high as those found in muscular tissue. Moreover, muscles form the larger part of the weight of the animal. Therefore the results of our calculations, based on the total weight and the MTU content of muscles, will not, in our opinion, be too high. Table VII shows the results of 5 calculations, concerning 5 animals slaughtered shortly (2-5.5 hours) after administration of MTU. These animals all received one dose of MTU only.

\section{TABLE VII}

Estimation of total amount of MTU

Interval = time interval between administration of MTU and slaughter.

Conc. = concentration of MTU in muscles, in milligrammes per cent.

Total $=$ the total amount of MTU, calculated according to text.

Perc. = the total amount of MTU, expressed as a percentage of the administered dose.

\begin{tabular}{|c|c|c|c|c|c|c|}
\hline No. & Dose & Interval & Weight & Conc. & Total & Perc. \\
\hline $\mathrm{R}$ & $120 \mathrm{mg}$ & 4.5 hours & $3^{820 \mathrm{~g}}$ & 2.5 & $96 \mathrm{mg}$ & $80 \%$ \\
\hline $\mathrm{T}$ & $80 \mathrm{mg}$ & 5.5 hours & $3570 \mathrm{~g}$ & $\mathrm{r} .3$ & $4^{8} \mathrm{mg}$ & $60 \%$ \\
\hline I I & $80 \mathrm{mg}$ & 5 hours & $1700 \mathrm{~g}$ & 2.3 & $39 \mathrm{mg}$ & $49 \%$ \\
\hline 12 & $80 \mathrm{mg}$ & 5 hours & $\mathrm{I} 800 \mathrm{~g}$ & 2.3 & $4 \mathrm{I} \mathrm{mg}$ & $51 \%$ \\
\hline I 3 & $80 \mathrm{mg}$ & 2 hours & $2100 \mathrm{~g}$ & 1.8 & $3^{8} \mathrm{mg}$ & $48 \%$ \\
\hline
\end{tabular}

The data of Table VII demonstrate a very rapid absorption of MTU from the digestive tract, especially if we take into account that considerable amounts of MTU may already have been excreted by way of the kidneys, while, moreover, destruction of MTU in the body may have occured. We therefore consider that all MTU is likely to be absorbed from the digestive tract in due time. Direct evidence for this assumption is provided by another experiment which will be described below.

References $p$. $I 6 I$. 


\section{The amounts of MTU in different parts of the gastro-intestinal tract}

The amounts of MTU in crop, gizzard, small intestine, caeca and rectum were determined with the method described by VAN ASPEREN ${ }^{3}$ for the excrements. In order to facilitate the interpretation of the results, raw potato starch was given simultaneously with MTU. The amounts of potato starch could be determined by counting the number of starch grains. The method will not be described here in detail.

First case: Animal $\mathrm{T}$ was slaughtered $5 \frac{1}{2}$ hours after the oral administration of $80 \mathrm{mg}$ MTU. Gizzard, small intestine, caeca and rectum contained nearly no MTU at all, the contents of the crop (only 2 gram) were not investigated. A small part of simultaneously administered potato starch was recovered from the rectum, the other parts of the gastro-intestinal tract contained no potato starch grains.

Second case: A second experiment, with Animal C, yielded better results. This animal received 2 grams of raw potato starch (Amylum Solani) and $80 \mathrm{mg}$ MTU, suspended together in a small amount of water, by means of a crop tube. After 2 hours the animal was killed, and the different parts of the gastro-intestinal tract were investigated. The results are to be found in Table VIII.

\section{TABLE VIII}

potato STARCh AND MTU IN THE DIGESTIVE TRACT

Perc. $=$ the amount expressed as a percentage of the administered dose.

\begin{tabular}{l|c|c|c|c}
\hline \multirow{2}{*}{$\begin{array}{c}\text { Doses: } \\
\text { 8 g Am. Sol. }\end{array}$} & \multicolumn{2}{|c|}{ Amylum Solani } & \multicolumn{2}{c}{ Methylthiouracil } \\
\cline { 2 - 5 } in mg & perc. & in mg & perc. \\
\hline Crop & $9 \mathrm{mg}$ & $0.5 \%$ & - & - \\
\hline Gizzard & $470 \mathrm{mg}$ & $23.5 \%$ & $3.75 \mathrm{mg}$ & $5 \%$ \\
\hline Small intestine & $330 \mathrm{mg}$ & $\mathbf{1 6 . 5} \%$ & $\mathrm{T.5} \mathrm{mg}$ & $2 \%$ \\
\hline Caeca & $0 \mathrm{mg}$ & $0 \%$ & $0.66 \mathrm{mg}$ & $\mathrm{r} \%$ \\
\hline
\end{tabular}

From the data in Table VIII the conclusion may be drawn that MTU disappears much more rapidly from the digestive tract than the potato starch grains. About $70-90 \%$ of these starch grains, however, proved to be destroyed in the digestive tract. This percentage was determined by a large number of experiments, not mentioned here. So MTU will very likely be eliminated to a still larger extent, either by destruction or by absorption. All these facts provide strong evidence in favour of our opinion that no passage of MTU through the gastro-intestinal tract into the excrements occurs and that all excretion of MTU takes place by way of the kidneys.

\section{DISCUSSION}

On comparing our results with those of BEZEM, LEVER, AND BRUNNEKREEFT ${ }^{5}$ very interesting conclusions may be drawn. The differences between their and our values can undoubtedly be explained by the use of totally different methods. Whereas we ourselves, 
with the colorimetric method according to the prescription of $\mathrm{MøRCH}^{12}$, determined the total amount of methylthiouracil, uracil and closely related substances (or, very conservatively, all substances with a $>\mathrm{C}=\mathrm{S}$ or a $\geqslant \mathrm{C}-\mathrm{SH}$ configuration), BEzEM, LEVER, AND BRUNNEKREEFT determined the quantity of radio-active sulphur originating from an orally administered dose of ${ }^{35} \mathrm{~S}$ labeled methylthiouracil. If we now take into account that, according to literature data and our own experience, derivatives of thiouracil are readily destroyed in the body, while this destruction leaves the radio-active $S$ unassaulted, it is easily understood that in most cases our concentration values will be lower than those of the above-mentioned authors. This may explain the high percentage of excretion $(60-70 \%)$ and the long duration of excretion (more than $2 \times 24$ hours) as found by these investigators. Similar differences exist between the concentration values found in the organs of cows fed MTU by the colorimetric method (VAN GENDEREN, VAN LIER, AND BEZEM ${ }^{10}$ ) and those found with the aid of the radio-sulphur method (Bezem, VAN Esch, AND PEeR ${ }^{4}$ ). The very low concentrations of MTU Bezem, Lever, AND BRUNNEKREEFT found in muscle tissue and blood 24 hours after administration of MTU are in full agreement with our results. Shortly after the administration, however, these values, according to our results, are much higher. Most probably the MTU present in muscle tissue some hours after the administration is partly removed and excreted by the kidneys, partly destroyed on the spot by the tissue. The very low ${ }^{35} \mathrm{~S}$ concentrations after 24 hours prove that little or no metabolites of MTU containing ${ }^{35} \mathrm{~S}$ are left in the muscles. The MTU contents in thyroid tissue are high, both in their and in our animals. According to literature (WILLIAMS ${ }^{13}$ ) thyroid tissue has a strong destructive action. Supposing the products of catabolism of MTU would remain in the thyroid tissue, a cumulation of radio-active sulphur after feeding MTU containing ${ }^{35} \mathrm{~S}$ may be expected. This may explain the very high "methylthiouracil"-concentration (Jo-40 $\mathrm{mg} \%$ ) as found by Bezem, Lever, and BrunnekreEFt. The concentrations we found with the colorimetric determination method were all in the range of $2-4 \mathrm{mg} \%$. VAN GENDEREN, VAN LIER, AND BEZEM ${ }^{10}$ found an average content of $6.5 \mathrm{mg} \%$ in thyroid tissue of cows fed MTU (daily dose $5 \mathrm{~g}$ MTU). Anyhow, concentrations in the thyroids are markedly higher than those in muscle tissue. This fact emphasizes the special rôle of the thyroids in the metabolism of MTU.

As to the toxicity of flesh of cockerels fattened by MTU we may state that no toxic effects need be feared if there is a time interval of about 24 hours between the feeding of MTU and slaughtering. If the interval is smaller, we nevertheless consider it very improbable that toxic effects will occur, as therapeutic doses (50 mg/day at least) are much higher than the amounts which may be ingested by the consumption of cockerels fed MTU.

\section{SUMMARY}

The metabolism of orally administered methylthiouracil (= MTU) was studied by chemical determinations in the excrements, the contents of the digestive tract, blood plasma, muscle tissue and the thyroids. Daily doses of $40,5^{\circ}, 80$, roo and $120 \mathrm{mg}$ MTU were used. From the results the following conclusions are drawn: I. About half of the amount of MTU may be recovered from the excrements within 24 hours after the administration; 2 . The excretion rate is maximal about 2-6 hours after the administration. Most of the excretion takes place within 12 hours, excretion is almost complete after 24 hours; 3 . In blood plasma and muscle tissue the maximal concentrations (2-4 $\mathrm{mg} \%$ ) are reached in 2-5 hours, after which a rapid decline occurs and no or very little MTU may be found after 20-24 hours; 4. Concentrations of MTU in thyroid tissue are markedly higher than those in muscle tissue. The differences, however, are much smaller than those found by other investigators; 
5. MTU is very rapidly absorbed from the gastro-intestinal tract. MTU is only excreted by way of the kidneys, no direct passage through the digestive tract into the excrements occurs; 6 . No cumulation of MTU in muscle tissue takes place.

All these facts favour the opinion that MTU may very easily penetrate into and be just as readily eliminated from body tissues.

\section{RÉSUMÉ}

Le métabolisme du 4-méthyl-2-thiouracile ( $=\mathrm{MTU})$ chez des cochets a été étudié par des déterminations chimiques de la substance dans les excréments, le continu du canal digestif, le plasma sanguin, le tissu musculaire et les thyroïdes. Les quantités journalières de MTU, qui ont été administrées, s'élevaient à 4\%, 50, 80, roo et $120 \mathrm{mg}$. Les conclusions, qui peuvent être tirées des résultats de nos recherches sont les suivantes: $I$. A peu près la moitié de la quantité administrée est retrouvée dans les excréments dans les 24 heures après l'administration; 2. La vitesse d'excrétion est la plus grande 2-6 heures après l'administration. La plus grande partie de l'excrétion a lieu dans les 12 heures, l'excrétion est a peu près terminée après 24 heures; 3 . Dans le plasma sanguin et le tissu musculaire les concentrations augmentent jusqu'à des valeurs de $2-4 \mathrm{mg} \%$ dans les $2-5$ heures, après quoi une diminution se produit. Au bout de 20-24 heures les concentrations sont très faibles; 4 . La proportion de MTU dans les thyroïdes est considérablement plus forte que dans le tissu musculaire; 5 . Le MTU est absorbé très facilement du canal digestif. L'excrétion n'a lieu que par les reins; 6 . Aucune accumulation de MTU n'a lieu dans les muscles.

Nous sommes d'opinion que le MTU peut pénétrer sans peine dans les tissus du corps et qu'il peut être éliminé tout aussi facilement.

\section{ZUSAMMENFASSUNG}

Der Stoffwechsel des 4-Methyl-2-thiouracils ( $=$ MTU) bei einige Monate alten Hähnchen wurde durch chemische Bestimmungen dieser Substanz im Kot, im Inhalt des Verdauungskanals, im Blutplasma, im Muskelgewebe und in den Schilddrüsen untersucht. Es wurden tägliche Mengen von 4o, 50, 80, roo und $120 \mathrm{mg}$ MTU verabreicht. Folgende Schlüsse können aus den Resultaten unserer Untersuchungen gezogen werden: I. Etwa die Hälfte der verabreichten Menge wird innerhalb 24 Stunden wieder ausgeschieden und kann also im Kot zurückgefunden werden; 2. Die Geschwindigkeit der Exkretion ist 2-6 Stunden nach der Verabreichung am höchsten. Die Ausscheidung findet grösstenteils in den ersten 12 Stunden statt. Nach 24 Stunden ist sie ungefähr vollendet; 3. Im Blutplasma und im Muskelgewebe werden die höchsten Konzentrationen (2-4 mg\%) nach 2-5 Stunden erreicht, danach findet eine ziemlich rasche Abnahme der Konzentrationen statt, so dass nach 20-24 Stunden die Werte sehr gering geworden sind; 4 . Das Schilddrüsengewebe enthält beträchtlich mehr MTU als das Muskelgewebe; 5. MTU wird sehr leicht aus dem Verdauungskanal resorbiert. Die Exkretion findet nur mittels der Nieren statt; 6 . Eine Anhäufung von MTU im Muskelgewebe wurde nicht festgestellt.

Wir haben also das MTU als einen Stoff kennen gelernt, der sehr leicht in die Gewebe eindringt und daraus eben so leicht wieder austritt.

\section{REFERENCES}

1 M. van Albada and P. UbBels, Landbouwkund. Tijdschr., 6r (1949) 852.

2 F. N. Andrews and E. E. Schnetzler, Poultry Sci., 25 (1946) 124.

3 K. van Asperen, Biochim. Biophys. Acta, 6 (1950) I87.

4. J. Bezem, G. J. van Esch, and H. G. Peer, Landbouwkund. Tijdschr., 6I (r949) 946.

5 J. J. Bezem, J. Lever, and F. Brunnerreert, Landbouwkund. Tijdschr., 61 (1949) 905.

B R. M. Blakely and R. W. ANDerson, Poultry Sci., 28 (I949) I85.

7 L. V. Domm and D. B. Blivaiss, Proc. Soc. Exptl Biol. Med., 57 (1944) 367.

8 A. M. Frens, Landbouwkund. Tijdschr., 6r (1949) 916.

2 H. van Genderen, K. L. van Lier, and J. de Beus, Biochim. Riophys. Acta, 2 (1948) 482.

10 H. VAN Genderen, K. L. VAN LiER, AND J. J. Bezem, Landbouwkund. Tijdschr., 6I (1949) 938.

11 H. L. Kempster and C. W. TURner, Poultry Sci., 24 (1945) 94.

12 P. Mørch, Acta Pharmacol. Toxicol., I (1945) 106.

${ }^{13}$ R. H. Williams, Arch. intern. Med., 74 (I944) 479.

14 L. E. A. Wright, Med.J. Australia, 33 (1946) 800. 